\title{
Serological Detection of I nfectious Bursa Disease Virus Antibodies in Domestic Birds in North Central States of Nigeria
}

\author{
Chukwuedo, A.A. ${ }^{1}$, Nwanki , 0.0. ${ }^{2}$, I bu, J .0. ${ }^{3}$ and Asala, 0.0. ${ }^{2}$ \\ ${ }^{1}$ Viral Research Division, National Veterinary Research Institute, P.O Box 207 Vom, Plateau state, Nigeria \\ ${ }^{2}$ Viral vaccine production division, , National Veterinary Research Institute, P.M.B. 01, Vom Plateau state, \\ Nigeria, ${ }^{3}$ Department of Veterinary Pathology and Microbiology, Federal University of Agriculture, \\ Makurdi, Benue state, Nigeria.
}

(Received: 02:03:2016; Accepted: 04:07:16)

\begin{abstract}
The detection and distribution of infectious Bursa disease (IBD) virus antibody among local species of birds was investigated in 4,655 sera sample using Agar Gel precipitation test (AGPT). The results showed that local chickens had the highest distribution with 446 $(9.58 \%)$ followed by ducks $218(4.68 \%)$, guinea fowl $131(2.81 \%)$, turkey $159(3.42 \%)$ while the pigeons had the lowest with $50(1.07 \%)$. The relative risk value showed that the chickens had the highest $\mathbf{4 0 . 5 8 \%}$ while the pigeons had the lowest $(5.62 \%)$. These imply that the chickens are more at risk, susceptible and have higher potential of being infected by the disease. Statistically, there was significant difference in the values, $p<0.05$ ( $t=$ $5.683, p=0.005$ at $95 \%$ C.I.(270.75 -788.05). The presence of IBD virus antibodies among these unvaccinated birds suggests that the birds were susceptible and are infected. It also imply that the birds have the potentials of becoming carriers and serve as source of spread of the disease to other susceptible birds.The outbreak of IBD in domestic birds with high mortality helps to reduce the much needed proteins from animals source. It is therefore suggested that effort should be made to vaccinate the local birds against infectious bursa disease in Nigeria.
\end{abstract}

Keywords: Antibody, IBD-virus, Domestic birds, Mortality, Susceptibility.

Correspondence: echitonyedo@yahoo.com

\section{Introduction}

Infectious Bursa Disease (IBD Gumboro disease) is an acute, highly contagious viral infection of young chickens throughout the world. It is a very important disease of poultry, resulting in major economic losses worldwide. Outbreaks of the disease affect mostly young chicks of 3-4 weeks old with high mortality. The layers and broiler birds are also affected (Gordon and Jordan, 1982; Chukwuedo et al.,2006; Okwori et al., 2006. Infectious bursa disease in infected birds appear suddenly and spreading rapidly with signs of depression, ruffle feathers diarrhea, dehydration, trembling prostration followed by death ( Fenner et al., 1987; Dash et al., 1991). It is caused by a double stranded RNA virus belonging to Birnaviridae family. However, several strains of IBD virus do exit (Eddy et a.,1985, Saif, 1991).
Meanwhile, four pathotypes of infectious bursa disease viruses namely attenuated virulent, antigenic variant and very virulent(VVIBDV) have been documented (Abdel-Alim and Saif, 2001) Since the first time the disease was described by Ojo (1973) in Nigeria, there have been reported cases of post-vaccination outbreak of IBD in poultry farms. From the available reports of infectious bursa diseases (Gumboro) though wide spread in Nigeria, most of the cases occurred in big poultry farms in the southern states of the country (Nawathe et al., 1978, Ahmed et al.,2003).

Although IBD virus vaccine is produced in Nigeria for over three and half decades, most poultry farmers especially in the villages and rural areas do not have access to the vaccines. This may be due to high cost of the vaccines, non-availability, lack of veterinary services, poor 
storage facilities, improper handling and administration of the vaccines resulting to outbreaks of IBD in poultry with high mortality. Also there are different types of infectious bursa disease vaccines imported into the country which may be cheaper but do not effectively protect the birds against the indigenous strains and serotypes. Chukwuedo et al., 2012) report in a pilot study that some foreign IBD vaccines may protect the birds but the immunity does not last long.

In 1992 the Federal Department of Livestock and Peste Control Services (FDLPCS) estimated 104.3 million poultry population in Nigeria. This comprises 72.4 million chickens, 11.8 million ducks, 4.7 million guinea fowls, 15.2 million pigeons and 0.2 million turkeys. The village poultry constitute over $90 \%$ and $90 \%$ of these birds are kept by the rural dwellers (Sonaiya, 1999; Ndegwa et al., 2000; Olabode and Chukwuedo, 2005)

In this study efforts are made to determine the distribution of IBD antibodies in apparently healthy local birds and the possible role(s) played by these free range birds in the transmission of the IBD virus, causing post vaccination disease outbreaks in the intensive poultry farming systems, resulting to high mortality and huge economic loss.

\section{Materials and Methods:}

Standard Antigen IBD Antiserum: The standard IBD virus antigens and antiserum were obtained from virus vaccine production divisions of the National Veterinary Research Institute (NVRI) Vom, Plateau State.

Blood Sera Samples: A total of four thousand six hundred and fifty-five $(4,655)$ blood samples were allowed to clot and the serum was carefully aspirated into sterile bijou bottles labeled appropriately and stored at $-20^{\circ} \mathrm{C}$ ready for use. The states sample distributions are; Abuja (761 samples), Plateau (781 samples), Kaduna (812 samples), Benue (749 samples), Kogi (781 samples) and Nasarawa (771 samples). The hosts sample distributions were; Chickens (1099 sera), Ducks (965 sera), Guinea fowls (834 sera), Turkeys (868 sera) and Pigeons (889sera) (Table 1).

Sample Treatment: The whole sera samples were heat inactivated by heating at $56^{\circ} \mathrm{C}$ in a water bath for 30 minutes to remove complements and other indeterminate inhibitors.
The sera were centrifuge at 3,000 rpm for $15 \mathrm{~min}$. to remove any Deloris, after which they were ready for assay.

Agar Gel Medium: Agarose gel was prepared in $1 \% \mathrm{w} / \mathrm{v}$ concentration containing $8 \%$ sodium chloride and $0.1 \%$ sodium azide in distilled water, PH 7.2 (purified oxide agar). The agar was melted and autoclave at $121^{\circ} \mathrm{Cfor}$ $10 \mathrm{~min}$ and allowed to cool to about $45^{\circ} \mathrm{C}$. The molten agarose was poured into $9 \mathrm{~cm}$ diameter disposable sterile Petri dishes and allowed to solidify at room temperature. Seven wells of $3 \mathrm{~min}$ in diameter were made in the agar plates using the standard gel puncher and a template for double diffusion the design consists of a central well surrounded by six equidistant satellite wells. The distance between two adjacent well was $4 \mathrm{~mm}$ while the distance between the central and adjacent wells was $3 \mathrm{~mm}$. The bottoms of the wells were filled with small molten agar to avoid reactants sip page.

Agar Gel Precipitation (Qualitative) Test: The pretreated test sera were added into the adjacent wells (including positive and negative controls) while the probe antigen was added to the central well. The plates were incubated at $37^{\circ} \mathrm{C}$ for $24-72$ hour in humidified chamber. The plates were examined and read under bright background. The positive reaction was indicated by the presence of fine precipitin line between the central and adjacent wells (Castello et al.,1987).

Agar Gel Precipitation (Quantitative) Test: Two fold serial dilutions from 1:2 to $1: 128$ of all positive IBD antibodies sera were prepared in sterile PBS, pH 7.2. The various dilution of each serum was dispensed into appropriate wells. The plates were incubated at $37^{\circ} \mathrm{C}$ for $24-$ 72 hour. In a humidified chamber and read as it was done in the case of quantitative test.

\section{Results}

Table 1 shows the distribution of samples according to the locations and the specie hosts. The highest number of samples came from Kaduna State, 812(17.44\%) followed by Plateau and Kogi States with $781(16.78 \%)$ while Benue State had the lowest, 749(16.09\%). The highest sera came from the chickens $1099(23.61 \%)$ followed by ducks, $965(20.73 \%)$ and pigeons with $889(19.10 \%)$ while the lowest came from the guinea fowls, 834(17.91\%) (Table1). The IBD virus antibody distribution 
among the birds species depicts that the local chickens had the highest frequency of the antibodies, $446(9.58 \%)$ followed by the ducks with $218(4.68 \%)$ while the pigeons had the lowest antibody distribution, 50(1.07\%). Also the relative risk was also highest with $40.58 \%$ among the local chickens and lowest in the pigeons, 5.62\% (Table 2).

Table 1: Distribution of different species of bird in the study location (states)

\begin{tabular}{lclllllll}
\hline \multicolumn{1}{c}{ location } & L. chickens & Ducks & G. fowl & Turkey & Pigeon & Total & t- value & p-values \\
\hline Abuja & 180 & 158 & 149 & 143 & 131 & 761 & 18.520 & 0.000 \\
Plateau & 177 & 174 & 132 & 158 & 140 & 781 & 17.459 & 0.000 \\
Kaduna & 185 & 178 & 141 & 151 & 157 & 812 & 19.613 & 0.000 \\
Benue & 169 & 142 & 137 & 138 & 163 & 749 & 22.247 & 0.000 \\
Kogi & 191 & 154 & 144 & 149 & 143 & 781 & 17.514 & 0.000 \\
Nasarawa & 197 & 159 & 131 & 129 & 155 & 771 & 12.530 & 0.000 \\
Total & $1099(23.61)$ & $965(20.73)$ & $834(17.91)$ & $868(18.65)$ & $889(19.10)$ & 4655 & --- & -- \\
\hline
\end{tabular}

$t=44.651 \quad t=29.682 \quad t=48.541 \quad t=34.440 \quad t=29.978$

$p=0.000 \quad p=0.000 \quad p=0.000 \quad p=0.000 \quad p=0.000$

Key: $(\quad)=$ percentage values, $\quad$ L. $=$ Local, G. $=$ Guinea

Table 2: Distribution of I BD virus antibodies among the different local bird specie

\begin{tabular}{ccllcl}
\hline Bird specie & $\begin{array}{l}\text { No of sample } \\
\text { tested }\end{array}$ & $\begin{array}{l}\text { Positive } \\
\text { samples (\%) }\end{array}$ & $\begin{array}{l}\text { Negative } \\
\text { samples (\%) }\end{array}$ & $\begin{array}{l}\text { Relative risk } \\
\text { (\%) }\end{array}$ & $\begin{array}{l}\text { Odd } \\
\text { ratio }\end{array}$ \\
\hline Local chickens & 1099 & $446(9.58)$ & $653(14.03)$ & 40.58 & 0.6830 \\
Ducks & 965 & $218(4.68)$ & $747(16.05)$ & 22.59 & 0.2918 \\
Guinea fowls & 834 & $131(2.81)$ & $703(15.10)$ & 15.71 & 0.1863 \\
Turkeys & 868 & $159(3.42)$ & $709(15.23)$ & 18.32 & 0.2242 \\
Pigeons & 889 & $50(1.07)$ & $839(18.02)$ & 5.62 & 0.0597 \\
Total & 4655 & $1004(21.57)$ & $3651(78.43)$ & - & 1.4449 \\
\hline
\end{tabular}

Key: $(\quad)=$ percentage values, $\quad t=5.683 \quad p=0.005$

* Data is significant at $\mathrm{P}<0.05$,

In Table 3, the results of the analysis showed that all the bird species had antibody to IBD which imply that they are all susceptible to the virus infections. The local chickens had the highest IBD antibody distribution, $87(1.87 \%)$ in Abuja followed by Kogi State with 82(1.76\%) while Benue state with 63(1.35\%) had the lowest. In the ducks, Benue sera had the highest, $47(1.01 \%)$ followed by Abuja with $43(0.92 \%)$ while the lowest was $24(0.53 \%)$ from Kaduna. The highest distribution among the guinea fowls was 34(0.73\%) from Nasarawa State, followed by Benue and Kogi state with $23(0.49 \%)$ respectively while the lowest was $11(0.24 \%)$ from Kaduna. In turkey sera, $41(0.88 \%)$ was the highest from Nasarawa State followed by $34(0.73 \%)$ from Benue while $13(0.28 \%)$ was the lowest from Plateau State. Among the pigeon, Abuja had the highest, $17(0.37 \%)$ followed by $13(0.28 \%)$ from
Nasarawa state while Kaduna State sera had the lowest with 5(0.11) (Table 3).

The results of quantitative AGPT analysis of seropositive sera and antibody titer range depicts that $872(18.73 \%)$ out of $1004(21.56 \%)$ had antibody titer range of $8-64$ while $132(2.83 \%)$ positive sera had a lower antibody titer range of 2-4. The highest titer of 64 was found among local chickens with 16-64 range, followed by the guinea fowls with titer range of 16-32 while ducks and turkey had 8-16 antibody titer range respectively (Table 4 ). Table 5 shows the five (2010-2014) distribution of samples obtained and antibody profile amongst the birds. More samples were obtained in 2013 and 2014 across all the birds screened. The IBD virus antibodies were highest in local chickens and lowest among the pigeons (Table $5)$. 
Table 3: Analysis of infections bursa disease virus Antibodies distribution

\begin{tabular}{|c|c|c|c|c|c|c|c|c|}
\hline \multirow{2}{*}{$\begin{array}{l}\text { Sample } \\
\text { location } \\
\text { (states) }\end{array}$} & \multirow{2}{*}{$\begin{array}{l}\text { Total } \\
\text { no. of } \\
\text { samples }\end{array}$} & \multicolumn{7}{|c|}{ Positive Birds Species Antibodies Distribution. } \\
\hline & & $\begin{array}{l}\text { Local } \\
\text { chickens }\end{array}$ & Ducks & $\begin{array}{l}\text { Guinea } \\
\text { fowl }\end{array}$ & Turkey & Pigeons & t-values & p-values \\
\hline Abuja & 761 & $87(1.87)$ & $43(0.93)$ & $21(0.45)$ & $25(0.54)$ & $17(0.37)$ & 2.994 & 0.040 \\
\hline Plateau & 781 & $68(1.46)$ & $35(0.75)$ & $19(0.41)$ & $13(0.28)$ & $0(0.00)$ & 2.309 & 0.082 \\
\hline Kaduna & 812 & $79(1.70)$ & $24(0.52)$ & $11(0.24)$ & $29(0.62)$ & $5(0.11)$ & 2.263 & 0.086 \\
\hline Benue & 749 & $63(1.35)$ & $47(1.01$ & $23(0.49)$ & $34(0.73)$ & $7(0.15)$ & 3.612 & 0.023 \\
\hline Kogi & 781 & $82(1.76)$ & $31(0.67)$ & $23(0.49)$ & $17(0.37)$ & $8(0.17)$ & 2.4766 & 0.069 \\
\hline Nasarawa & 771 & $67(1.44)$ & $38(0.73)$ & $34(0.73)$ & $41(0.88)$ & $13(0.28)$ & 4.473 & 0.011 \\
\hline Total & 4655 & $446(9.58)$ & $218(4.68)$ & $131(2.81)$ & $159(3.42)$ & $50(1.07)$ & - & - \\
\hline
\end{tabular}

Key: ( ) = percentage values.

Table 4: Quantitative AGPT analysis of sero positive sample and antibody ranges

\begin{tabular}{|c|c|c|c|c|c|c|}
\hline $\begin{array}{l}\text { Birds } \\
\text { specie }\end{array}$ & $\begin{array}{l}\text { samples } \\
\text { Tested (a) }\end{array}$ & $\begin{array}{l}\text { No. Positives } \\
\text { (\%) (b) }\end{array}$ & $\begin{array}{l}\text { Positives }>1: 8 \\
(\%) \text { (c) }\end{array}$ & $\begin{array}{l}\text { Titre } \\
\text { Range }\end{array}$ & $\begin{array}{l}\text { Positives <1:4 } \\
\begin{array}{ll}(\%) & \text { (d) }\end{array}\end{array}$ & $\begin{array}{l}\text { Titre } \\
\text { range }\end{array}$ \\
\hline L. chickens & 1099 & $446(9.58)$ & $397(8.533)$ & $16-64$ & $49(1.05)$ & $2-4$ \\
\hline Ducks & 965 & $218(6.68)$ & $191(4.10)$ & $8-16$ & $27(0.58)$ & $2-4$ \\
\hline G. fowls & 834 & $131(2.81)$ & $118(2.54)$ & $16-32$ & $13(0.27)$ & $2-4$ \\
\hline Turkeys & 868 & $159(3.42)$ & $125(2.69)$ & $8-16$ & $34(0.73)$ & $2-4$ \\
\hline Pigeons & 889 & $50(1.07)$ & $41(0.88)$ & $\geq 8$ & $9(0.19)$ & $2-4$ \\
\hline Total & 4655 & $1004((21.56)$ & $872(18.73)$ & - & $132(2.83)$ & - \\
\hline
\end{tabular}

Key ()$=$ percentage values-comparing $a$ and $b, t=23.525, p=0.000, L .=$ Local, G. $=$ Guinea Comparing $c$ and $d, \quad t=2.723, p=0.050, \quad$ data significant at $P<0.05$

Table: 5 Distributions of IBDV Antibody among the different bird species in five sampling periods.

\begin{tabular}{lllll}
\hline Bird Species & Year of Study & No. of Samples & No. Positive & \% Positive \\
\hline L. Chickens & 2010 & 150 & 61 & 1.31 \\
& 2011 & 207 & 89 & 1.91 \\
& 2012 & 225 & 93 & 1.20 \\
Ducks & 2013 & 255 & 107 & 2.30 \\
& 2014 & 262 & 96 & 2.06 \\
& 2010 & 161 & 36 & 0.77 \\
& 2011 & 171 & 43 & 0.92 \\
G. Fowls & 2012 & 191 & 46 & 0.99 \\
& 2013 & 223 & 53 & 1.14 \\
& 2014 & 213 & 40 & 0.86 \\
& 2010 & 74 & 17 & 0.37 \\
Turkeys & 2011 & 150 & 24 & 0.52 \\
& 2012 & 179 & 31 & 0.67 \\
& 2013 & 200 & 33 & 0.71 \\
& 2014 & 231 & 26 & 0.56 \\
& 2010 & 83 & 19 & 0.41 \\
Pigeons & 2011 & 148 & 33 & 0.71 \\
& 2012 & 183 & 41 & 0.88 \\
& 2013 & 219 & 35 & 0.75 \\
& 2014 & 235 & 31 & 0.67 \\
& 2010 & 110 & 3 & 0.07 \\
& 2011 & 181 & 5 & 0.11 \\
& 2012 & 200 & 14 & 0.30 \\
& 2013 & 201 & 17 & 0.37 \\
\hline
\end{tabular}

Key: $\mathrm{N}=4655$. 


\section{Discussion}

The results of this study have shown that unvaccinated apparently health local birds are susceptible to IBD virus infection and it has also confirmed the findings of other workers that local birds are infected by infectious bursa disease and the prevalence of infectious bursa disease virus antibodies in these birds are high in Nigeria. It has specifically shown evidence that local chickens, ducks, guinea fowls, turkeys and pigeons are infected by IBD virus in the central states of Nigeria. This may imply that these birds are capable of becoming carriers and source of spread of infectious bursa disease virus infection to other susceptible birds and possibly cause post vaccination infection and out breaks in exotic poultry birds. The distribution of the bird species in their sample location shows that local chickens had more samples (1099) because they are more in population (Table1).

The detection of positive infectious bursa disease virus antibodies by AGPT in all the species of birds screened shows that all these species are susceptible, exposed and are infected by IBD virus. It is an evidence to confirm that there are wild infectious bursa disease virus strains or related strains or even a prototypes of the virus circulating among the local chickens, ducks, guinea fowls, turkeys and pigeons in the study area (Table 2 and 3 ). This finding is similar to the work of Gordon and Jordan (1982) who reported that IBD virus antibodies is wide spread in the central part of northern Nigeria among domestic fowls whether in commercial flocks or in free ranging. However, the finding differs slightly from Gordon and Jordan (1982) who failed to detect IBD viral antibody in guinea fowls (Table 3 ).

The quantitative analysis of these results depicts that local chickens had the highest antibody titer range, 16-64, followed by guinea fowls with 16-32, ducks and turkey had 8-16 titer range respectively while the highest titer in pigeon was > 8. Approximately $872(18.73 \%)$ out of $1004(21.56 \%)$ gave precipitin lines while $132(2.83 \%)$ show precipitin lines at dilutions $2-4$ in agar gel. The high frequency of infectious bursa disease virus antibodies among the local chickens with titer of 64 suggest that the chickens are more susceptible and infected than other species of birds screened (Table 4).

In Nigeria we have some militating factors against the infectious bursa disease control and prevention. The pockets of sporadic outbreaks of infectious bursa in local or domestic birds within the small household population in the rural villages are not reported because of the low economic values attached to them as compared with the established large population of exotic birds in poultry farms. In many homes the local birds are not reared strictly for economic values rather for mere ownership or for use at festive times and ceremonies. The neglect on the birds' health status, good management practices or disease condition helps to incubate, propagate and spread the disease to other susceptible birds and also maintain the disease within the areas or villages. Because the birds scavenge around the villages, their breeding and maintenance are at no cost to their owners and it also exposes the birds to a wide range of disease pathogens like IBD with high mortality.

Although these birds presents evidence of positive IBD virus antibodies but appeared apparently healthy, suggest that they may be carriers of IBD virus that will pose a big threat to any close susceptible exotic poultry birds. Okeke (1983) also pointed out that the importance of this disease does not lie on the mortality rate caused by the virus alone, but also immune suppressive effects leading to the susceptibility of the birds to other pathogens which can lead to great economic loses. However, we would like to mention some major constraints encountered in our study. These include (1) We have the inability to get equal number of birds specie in all the study locations. (2) There was lack of fund for some logistics like study visits and to purchase of vital materials for virus isolation due to large number of samples. (3) The bird owners often do not want to cooperate in allowing their birds to be investigated and bled for sample collection.

\section{Conclusion}

Infectious bursa disease is an important economic and dreaded disease of poultry birds in Nigeria. The infection of these birds were possible because there is a free movement of migratory birds from one state to another, hence could serve as potential route of the virus spread in Nigeria. For us to completely control and prevent IBD virus infection on our birds, improve and increase our poultry and protein supply there is urgent need to develop vaccine and vaccination program for local birds. The result of this study strongly suggested that a holistic approach must be adopted, which will include all species of birds in the prevention of 
IBD outbreaks in the north central zone of the country. However, because of the migratory system or pattern of these birds, (i) we support any outreach strategy to prevent infectious bursa disease among the local (domesticated) birds. (ii) We suggest that the offer of infectious bursa disease virus vaccines to the stake holders might be a reasonable strategy to prevent future infectious bursa disease outbreaks. (iii) The foundation strategy for eliminating IBD nationwide should be based on the regular and timely vaccination of these birds in the country. This will help to increase the animal protein supply, improve poultry farmer's income and alleviate their poverty in Nigeria. Given that $99.37 \%$ of the results obtained in this study came from birds with no clinical signs, the epidemiology of IBD viruses in Nigeria deserves to be thoroughly investigated nation wide with virus isolation and determination of the virus phylogenesis.

\section{Acknowledgement}

We are grateful to the Provost of federal college of veterinary and medical laboratory for his permission to use their virology laboratory. The authors would like to thank M.Y. Jabiru for statistical analysis and all the Technicians who contributed to the success of this project.

\section{References}

Ahmed, Z., Inayat, S., Naeem, K. and Malik, S.A. (2003). Comparative Immune response pattern of commercial infectious bursal Disease vaccines against field isolates in Pakistan. Int. J. Poultry Sci 2(6): 449-453.

Castello, I., Martinez, B.L. and Heronodez, k. (1987). Comparison of the agar Gel precipitation, virus neutralization and enzyme-linked Immune sorbent ass cy in the determination of antibodies to Infection bursa disease virus. VeterinarianMexico, 18:317-323.

Chukwuedo, A. A., Olabode, A.O. and Okolie, C.E. (2006). Comparative studies on the immune genicity of formation mactivated Vaccines with live attenuated NVRI gumboro vaccine in Nigeria. Nig. J Microbial 20 (3) 1129-1134.
Dash, B.B., Boer, G.F., Smith, S.R. and Hull, F.D. (1991). Pathogenicity of a field isolate of IBDV in chickens. Ind .J.Vet. Pathl. 15(1): 21-25.

Eddy, R.K., Allan, S.M. Adams, R.R. and Scott, P.P. (1985). Serological survey of the incidence of IBD sero type 1 and 2 in chickens and turkey flocks in England. Vet. Record 117, 415.

Fenner, F.F., Leo, S.G., Brandt, T.S. and Oscar, B. (1987). Birnaviridae: in veterinary virology Academic press, Florida, USA pp.595-600.

Gordon, R.F. and Jordan, F.T.W. (1982). Poultry disease $2^{\text {nd }}$ edition. Baitliere, Tindall, London. Pp 139-143

Nawathe, D.R., Onunkwo, O. and Smith, I.M (1978). Serological evidence of infection with the virus of infectious bursa disease in wild and domestic birds in Nigeria. Vet. Res. 102:444.

Ojo, M.O., Ade, O.J. and Adigun, A.A. (1973). Gumboro like disease in Nigeria. Trop. Ani HIth. Prod. 5:52-56.

Okeke, E.N. (1983). Infectious bursa disease (Gumboro). Proceedings on National workshop on disease of livestock and poultry. Jan. pp.24-27, 1983,

Okwori, A.E.J., Echeonwu, G.O.N., Olabode, A.O., J unaid, S.A., Abechi, S.A., Chukwuedo, A.A. and Aba-Adulugba, E.P. (2006). Serological survey of local poultry for Infectious Bursa Disease Virus (IBDV) antibodies using Agar Gel Precipitation Test (AGPT) in Jos, Plateau state, Nigeria. Nig J. microbial. 20 (3):1208-1213.

Saif, Y.M (1991). Immune suppression induced by infectious bursa disease virus. Vet. Immuno. Immunopathl. 30:45-50. 